\title{
Development and Sensory Evaluation of Biscuit by Incorporation of Carrot Powder
}

\author{
G. Mounika ${ }^{1 *}$ and Srinivas Maloo ${ }^{2}$ \\ ${ }^{1}$ Food Processing Technology, University College of technology, Osmania University, \\ Hyderabad, Telangana, India \\ ${ }^{2}$ University College of technology, Osmania University, Hyderabad, Telangana, India \\ *Corresponding author
}

\section{A B S T R A C T}

\begin{tabular}{|l|}
\hline Ke y w o r d s \\
Carrot-carotenoids, \\
Dietary fiber, \\
Antioxidants, Pomace, \\
Functional products \\
\hline Article Info \\
\hline Accepted: \\
20 March 2018 \\
Available Online: \\
10 April 2018 \\
\hline
\end{tabular}

Keywords

Article Info

20 March 2018

10 April 2018
Carrot is one of the important root vegetables rich in bioactive compounds like carotenoids and dietary fibers with appreciable levels of several other functional component shaving significant health-promoting properties. The consumption of carrot and its products is increasing steadily due to its recognition as an important source of natural antioxidants having anticancer activity. The purpose of this paper is to develop biscuit incorporated with carrot powder to enhance the nutritional value of it. The proportion of refined wheat flour and carrot powder were 97:3, 94:6, 91:9 and with these flour blends and used for making biscuit samples were $0,3,6,9 \%$ respectively. The biscuits were evaluated for its sensory test.

\section{Introduction}

The carrot (Daucus carota) is a root vegetable. Carrot is also an excellent source of calcium pectate an extraordinary pectin fiber that has the cholesterol lowering properties. It has a property to reduce the risk of high blood pressure, stroke, heart disease and some type of cancer.

Carrot (Daucus carota) is one of the nutritious vegetable consumed in raw and processed form throughout the world. In recent years, the consumption of carrot and its related products have increased steadily due to recognition of antioxidant and anticancer activities of betacarotene in carrot, which is also a precursor of vitamin A (Kotecha et al., 1998; Speizer et al., 1999). Carrot is the richest source of c, iron, pectin, dietary fibres, complex carbohydrates and various minerals. Carrot could be consumed raw or in processed form or can be fortified in a variety of food products. Lee $e t$ al., (2003) found decreased lipid oxidation rate in carrot powder added in fried dough. Different workers have successfully utilized antioxidant properties of carrot.

Vegetables are good sources of fibers, minerals and vitamins. They are cheaper and 
easily available, but are seasonal and highly perishable. Nearly 40 per cent of vegetables go waste due to their perishable nature, lack of appropriate post-harvest infrastructure and transportation, inadequate marketing set up and processing.

The red variety of the carrot root has been reported to contain higher concentrations of lycopene $(10 \mathrm{mg} / 100 \mathrm{~g})$ even higher than tomatoes (Grassman et al., 2007) and almost absent in $\alpha$ - carotene (Koch and Godman, 2005). The study based on five European countries showed ingestion of carrots in the diet contributed $60-90 \%$ of total $\beta$-carotene taken by the humans (Maiani et al., 2009).

Biscuit is one of the oldest commonly consumed non fermented baked snacks. Biscuits are anytime munching breakfast or snacks item. It is a quick hunger satisfying food. Working class face shortage of time, so biscuits become handy snacks for them. Biscuits are considered as best option for students, given their pocket money constraints.

Respondent of different age group were selected to know their eating habits and perception towards healthy and nutritious biscuits, because biscuits are consumed across all age groups (Dr. Jigna Chandra Kant Thrived et al., 2016).

The word 'Biscuit' is derived from the Latin words 'Bis' (meaning 'twice') and 'Coctus' (Meaning cooked or baked). The word 'Biscotti' is also the generic term for cookies in Italian (Dr. Jigna Chandra Kant Thrived et al., (2016).

The objective of this study on Preparation of Carrot powder from dried carrot, Preparation of biscuit from wheat and carrot mixed powder, Sensory evaluation of biscuit by incorporation of carrot powder.

\section{Materials and Methods}

Refined wheat flour, carrots, RBD (brand name "BRITE"), sugar, salt, milk powder, ammonia bicarbonate used for biscuit making were purchased from local market in Hyderabad (India).

\section{Drying method}

\section{Tray dryer}

Selected carrots that are fresh and crisp, peel them, and cut them into 5 to $6 \mathrm{~mm}$ thick slices. The sliced carrots dried in a Tray drying at $80^{\circ} \mathrm{c}$ for $6-8 \mathrm{hr}$. The dried carrot was grinding in mixer and sieved with a $2 \mathrm{~mm}$ sieve and was packaged in polythene bag for further uses.

\section{Sample preparation}

Ingredient formulations for biscuit products are given in Table 1. Fine wheat flour was replaced with carrot powder at levels of $0 \%$, $3 \%, 6 \%$ and $9 \%$.

The ingredients were mixed in the same food processor with mixer attachment. All the ingredients were again mixed in the same food processor for 10 minute based on preliminary study.

The weighed quantity of refined wheat flour, carrot powder and sugar powder is sieved and is then mixed properly with above mix with RBD and invert syrup. Then milk powder, ammonia bicarbonate and salt are added to it. It is mixed well with to a proper consistency like a soft dough.

Then a spoon full of dough is poured on a greased tray. It is then baked in oven at temperature maintained $180^{\circ} \mathrm{C}-200^{\circ} \mathrm{C}$ for 15 minutes. The baked biscuits were cooled for about 30 minutes, packed in polybags till the evaluation of responses and sensory analysis. 


\section{Results and Discussion}

\section{Sensory analysis of biscuits}

Sensory Evaluation for the biscuits was conducted using 3 formulation of carrot powder. The sensory scores suggested that sample B (6\%Carrot powder) had maximum acceptability. Compare to Control sample, sample A (3\% carrot powder) and sample C (9\% carrot powder)

\section{Control biscuits}

Appearance of control biscuit is 0th day scored 7 and 5th Month having 6.5.

Similarly Colour, flavor, taste, texture and Overall acceptability of the control biscuit scores were decreased.
Compared to 0th day to 5th month the sample score was decreased. When increasing the storage period appearance, Colour, flavor, Taste, Texture and overall acceptability changes were observed.

\section{Sample -A (3\%)}

The score for taste was found highest in $0^{\text {th }}$ day with a score of 7.2 as compared to $1^{\text {st }}$ to $5^{\text {th }}$ months of biscuit sample- A (3\%)

Appearance of sample- A is $0^{\text {th }}$ day scored 7 and $5^{\text {th }}$ Month having 6.9. Similarly Colour, flavor, taste, texture and Overall acceptability of the sample A scores were decreased. Compared to $0^{\text {th }}$ day to $5^{\text {th }}$ month the sample score was decreased. When increasing the storage period appearance, Colour, flavor, Taste, Texture and overall acceptability changes were observed.

Table.1 Composition of biscuit with incorporation of carrot powder

\begin{tabular}{|c|c|c|c|c|c|}
\hline S. No. & Ingredients & $\begin{array}{c}\text { Controlled } \\
(0 \%)\end{array}$ & $\begin{array}{c}\text { Sample-A } \\
(3 \%)\end{array}$ & Sample-B (6\%) & $\begin{array}{c}\text { Sample-C } \\
(\mathbf{9 \%})\end{array}$ \\
\hline 1 & $\begin{array}{l}\text { Maida (refine wheat } \\
\text { flour) }(\mathrm{g})\end{array}$ & 100 & $97 \mathrm{~g}$ & $94 \mathrm{~g}$ & $91 \mathrm{~g}$ \\
\hline 2 & Carrot powder & - & $3 g$ & $6 g$ & $9 g$ \\
\hline 3 & RBD & $15 \mathrm{~g}$ & $15 \mathrm{~g}$ & $15 \mathrm{~g}$ & $15 \mathrm{~g}$ \\
\hline 4 & Sugar & $40 \mathrm{~g}$ & $40 \mathrm{~g}$ & $40 \mathrm{~g}$ & $40 \mathrm{~g}$ \\
\hline 5 & Salt & $1 \mathrm{~g}$ & $1 \mathrm{~g}$ & $1 \mathrm{~g}$ & $1 \mathrm{~g}$ \\
\hline 6 & Water & $20 \mathrm{ml}$ & $20 \mathrm{ml}$ & $20 \mathrm{ml}$ & $20 \mathrm{ml}$ \\
\hline 7 & Milk powder & $5 g$ & $5 g$ & $5 g$ & $5 g$ \\
\hline 8 & Ammonia bicarbonate & $1 \mathrm{~g}$ & $1 \mathrm{~g}$ & $1 \mathrm{~g}$ & $1 \mathrm{~g}$ \\
\hline
\end{tabular}


Table.2 Sensory score of control biscuits

\begin{tabular}{|l|l|l|l|l|l|l|}
\hline Sensory attributes & $0^{\text {th }}$ day & $1 \mathrm{M}$ & $2 \mathrm{M}$ & $3 \mathrm{M}$ & $4 \mathrm{M}$ & $5 \mathrm{M}$ \\
\hline Appearance & 7 & 6.5 & 7.2 & 6.8 & 6.5 & 6.5 \\
\hline Colour & 6.9 & 6.8 & 6.7 & 6.8 & 6.9 & 6.8 \\
\hline Flavour & 6.8 & 6.7 & 6.5 & 6.3 & 6.8 & 6.5 \\
\hline Taste & 6.5 & 6.8 & 6.5 & 7 & 6.7 & 6.9 \\
\hline Texture & 6.9 & 6.8 & 7 & 6.8 & 6.9 & 6.8 \\
\hline Overall acceptability & 7 & 7 & 6.8 & 7 & 6.9 & 6.5 \\
\hline
\end{tabular}

Table.3 Sensory score of biscuit sample-A (3\%)

\begin{tabular}{|l|c|c|c|c|c|c|}
\hline Sensory attributes & 0 th day & $1 \mathrm{M}$ & $2 \mathrm{M}$ & $3 \mathrm{M}$ & $4 \mathrm{M}$ & $5 \mathrm{M}$ \\
\hline Appearance & 7 & 7 & 6.9 & 6.8 & 7 & 6.9 \\
\hline Colour & 6.7 & 6.5 & 6.3 & 6.8 & 6.5 & 6.7 \\
\hline Flavour & 6.8 & 6.8 & 6.5 & 6.3 & 6.3 & 6 \\
\hline Taste & 7.2 & 7 & 6.8 & 6.5 & 6.8 & 6.5 \\
\hline Texture & 7 & 6.5 & 6.3 & 6 & 6.3 & 6.2 \\
\hline Overall acceptability & 6.9 & 6.7 & 6.5 & 6.3 & 6.8 & 6.9 \\
\hline
\end{tabular}

Table.4 Sensory score of biscuit sample-B (6\%)

\begin{tabular}{|l|c|c|c|c|c|c|}
\hline Sensory attributes & 0th day & $1 \mathrm{M}$ & $2 \mathrm{M}$ & $3 \mathrm{M}$ & $4 \mathrm{M}$ & $5 \mathrm{M}$ \\
\hline Appearance & 7.6 & 7.3 & 7.4 & 7.3 & 7.1 & 6.9 \\
\hline Colour & 7.3 & 7.2 & 7.1 & 7 & 6.9 & 6.7 \\
\hline Flavour & 7.1 & 7 & 6.8 & 6.5 & 6.2 & 6.3 \\
\hline Taste & 7.4 & 7.3 & 7.1 & 6.9 & 6.3 & 6.5 \\
\hline Texture & 7.1 & 7 & 6.9 & 6.7 & 6.5 & 6.2 \\
\hline Overall acceptability & 7.3 & 7.2 & 7 & 6.9 & 6.8 & 7 \\
\hline
\end{tabular}


Table.5 Sensory score of sample-C (9\%)

\begin{tabular}{|l|c|c|c|c|c|c|}
\hline Sensory attributes & $\begin{array}{c}\text { 0th } \\
\text { day }\end{array}$ & $1 \mathrm{M}$ & $2 \mathrm{M}$ & $3 \mathrm{M}$ & $4 \mathrm{M}$ & $5 \mathrm{M}$ \\
\hline Appearance & 7.4 & 7 & 6.8 & 6.7 & 6 & 6 \\
\hline Colour & 7.2 & 7.1 & 7.2 & 6.9 & 6.7 & 6.5 \\
\hline Flavour & 7.1 & 7.1 & 6.8 & 6.5 & 6.3 & 6 \\
\hline Taste & 7 & 6.8 & 6.7 & 6.5 & 6 & 6 \\
\hline Texture & 7 & 7 & 6.9 & 6.7 & 6.8 & 6.2 \\
\hline Overall acceptability & 7.2 & 7 & 7 & 6.8 & 6.5 & 6 \\
\hline
\end{tabular}

Process flow chart for the carrot powder

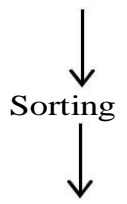

Washing with potable water






\section{Process flow chart for the Biscuits}

Weighing of ingredients

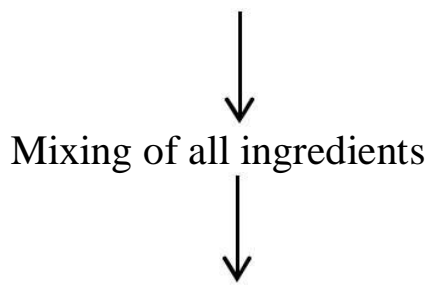

Dough kneading

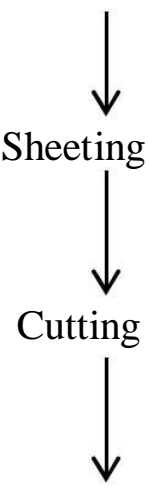

Baking in oven $\left(180-200^{\circ} \mathrm{c}\right)$ for $15 \mathrm{~min}$

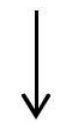

Cooling (30 min)

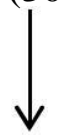

Packaging (HDPE)

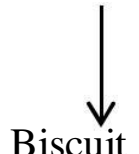

Fig.1 Carrot slices before and after drying

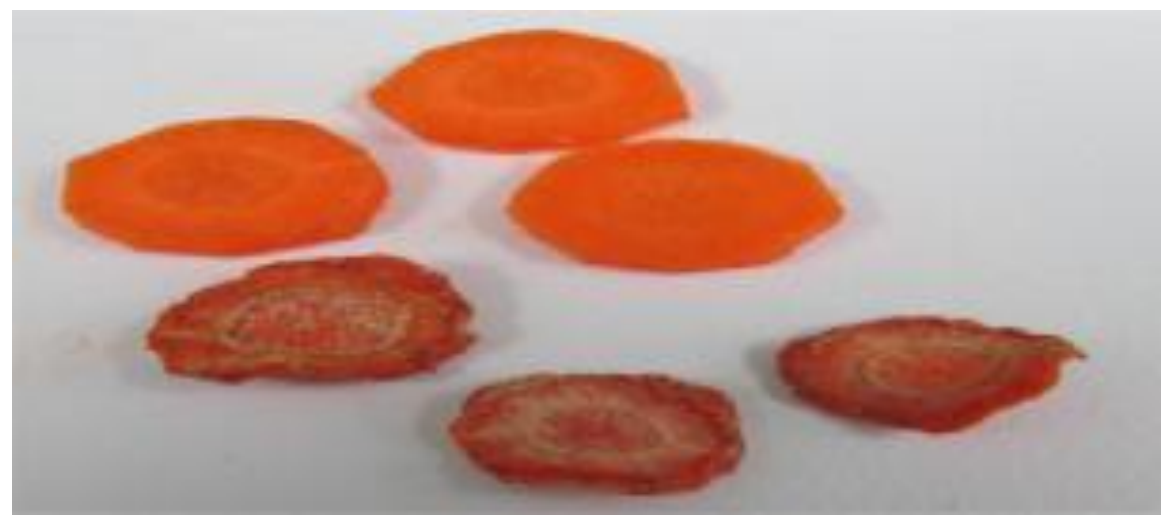


Int.J.Curr.Microbiol.App.Sci (2018) 7(4): 2583-2592

Fig.2 Sensory characteristic of control biscuits

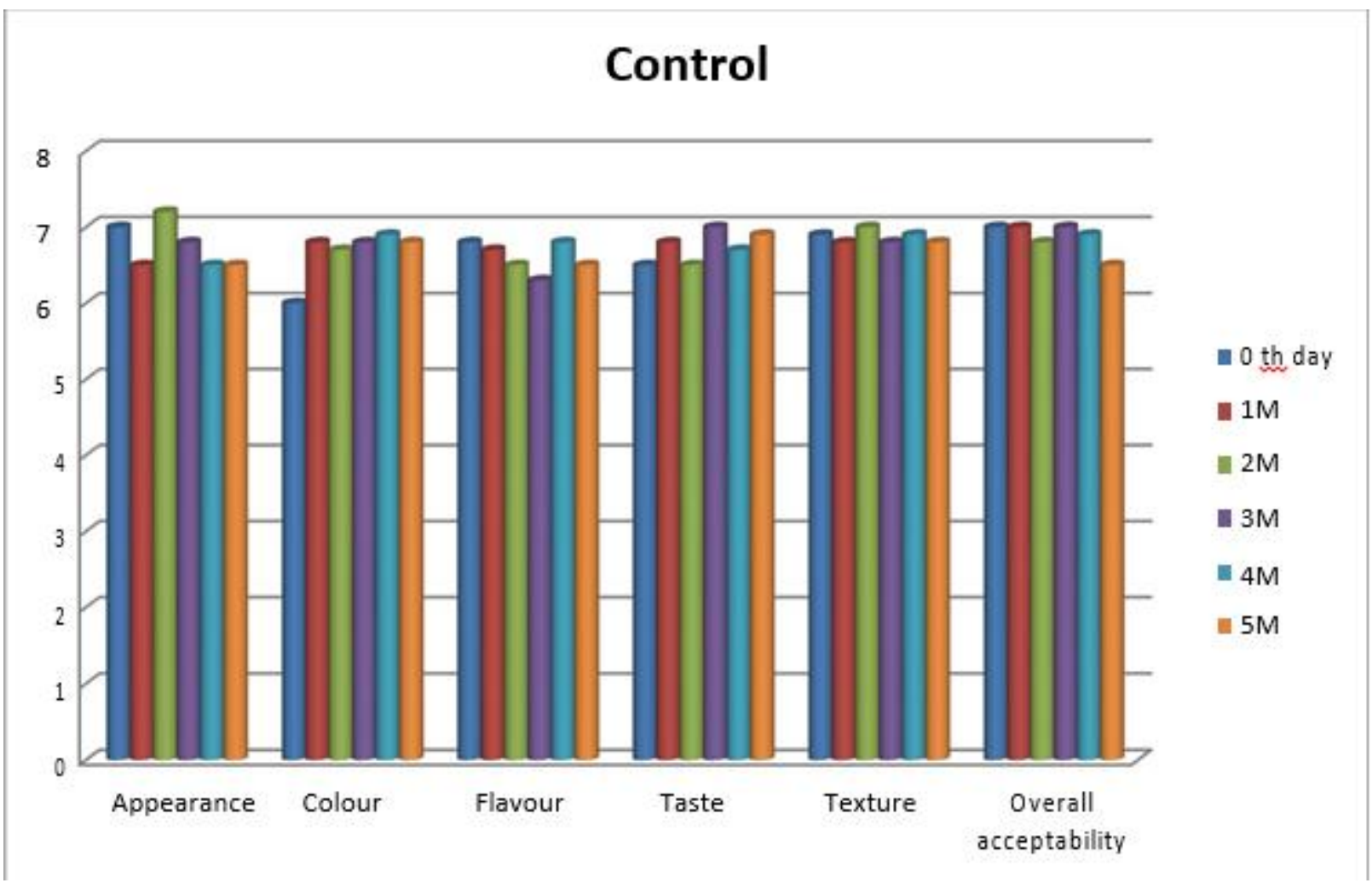

Fig.3 Sensory characteristic of biscuit sample-A (3\%)

\section{SAMPLE- $A(3 \%)$}

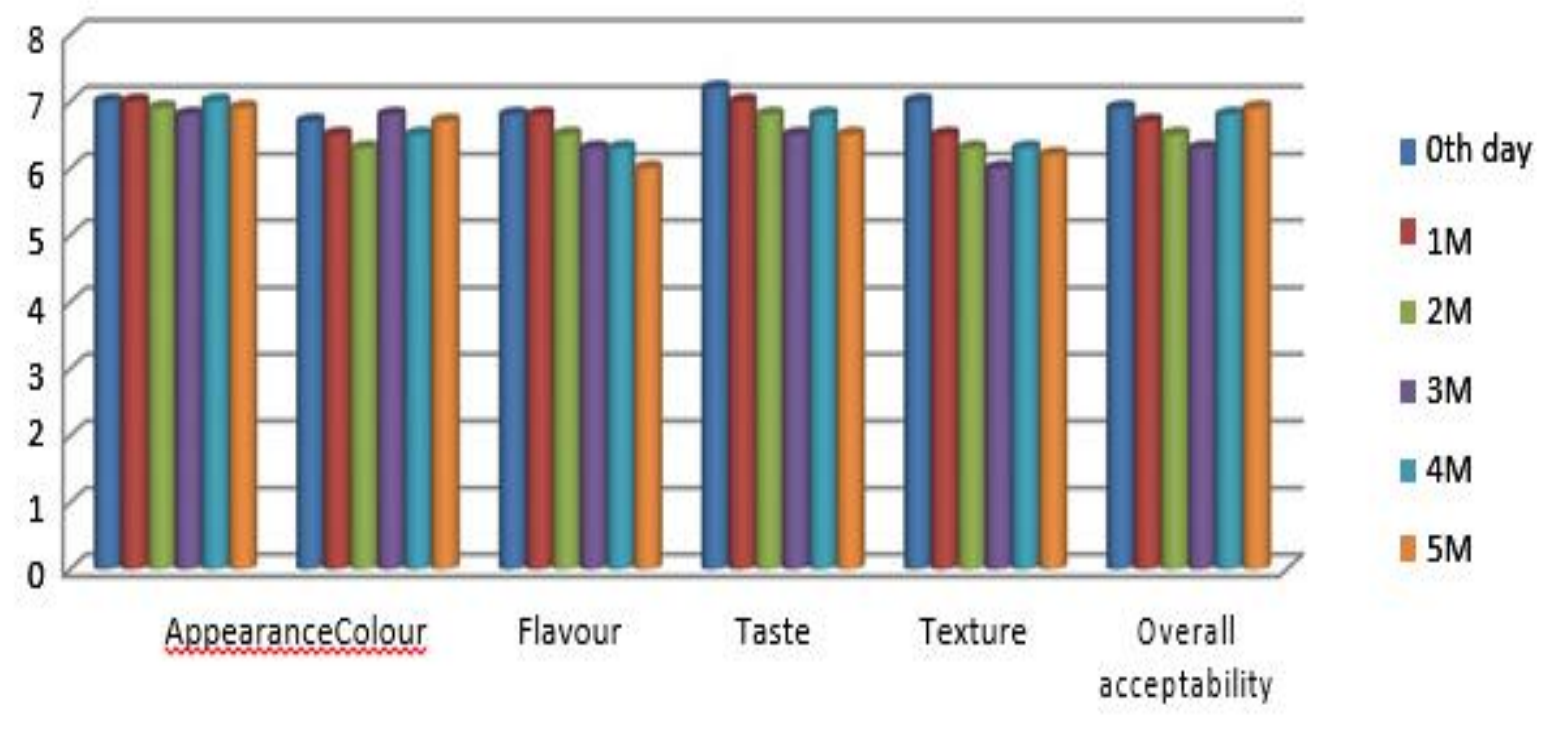


Fig.4 Sensory characteristic of biscuit sample-B (6\%)

\section{SAMPLE -B (6\%)}

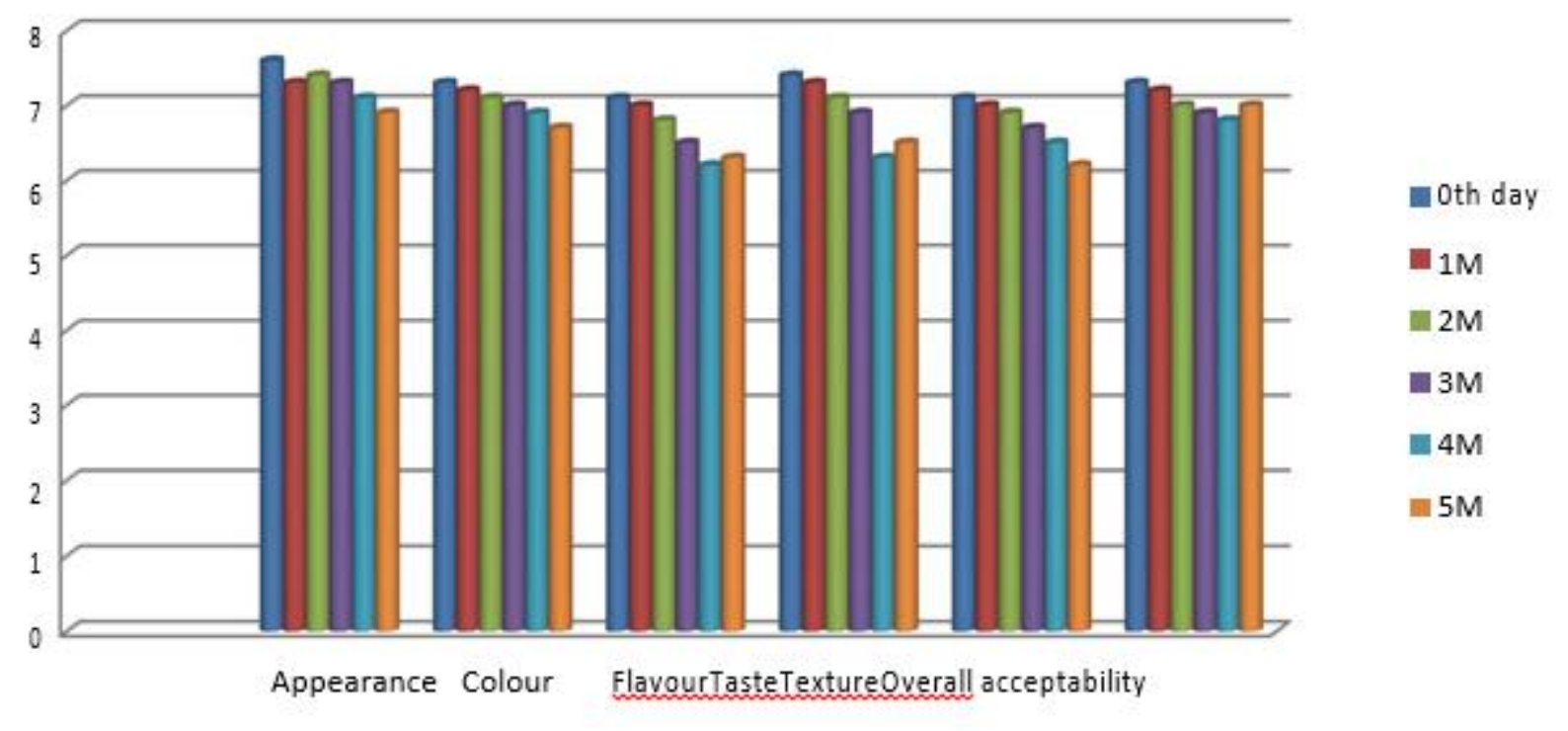

Fig.5 Sensory characteristic of biscuit sample-C (9\%)

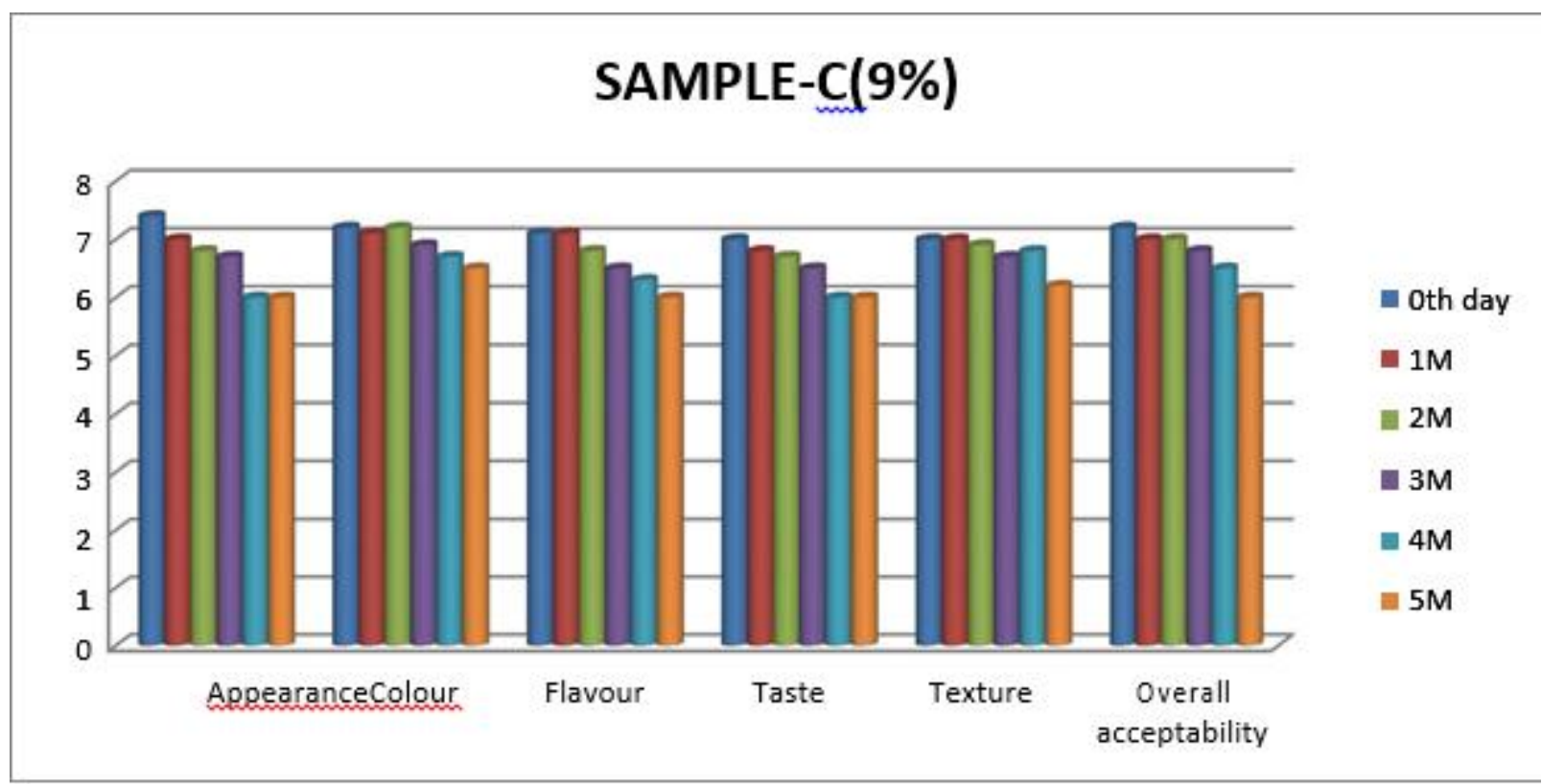

Sample-B (6\%)

The score for Appearance, taste and colour, was found highest in 0th day with a score of 7.6, 7.4 and 7.3 as compared to Other Biscuit samples. Appearance of e sample-B is 0th day scored 7.6 \& 5th Month having 6.9.similarly Colour, flavor, taste, texture \& Overall acceptability of the sample B scores were decreased. Compared to 0th day to 5th month the sample score was decreased. When increasing the storage period appearance, 
Colour, flavor, Taste, Texture and overall acceptability changes were observed.

\section{Sample-C (9\%)}

The score for appearance and colour was found highest in $0^{\text {th }}$ day with a score of 7.4 and 7.2 as compared to other Biscuit samples

Appearance of e sample-C is $0^{\text {th }}$ day scored 7.4 and $5^{\text {th }}$ Month having 6.similarly Colour, flavor, taste, texture \& Overall acceptability of the sample-C scores were decreased. Compared to $0^{\text {th }}$ day to $5^{\text {th }}$ month the sample score was decreased. When increasing the storage period appearance, Colour, flavor, Taste, Texture and overall acceptability changes were observed.

The acceptability of carrot powder and wheat flour mixed biscuit were evaluated interns of colour, flavor, texture and overall acceptability by taste panel members. As per sensory analysis it was found that sample-B (6\% Carrot powder) secured the highest score. Compare to other biscuit samples (control, sample-A (3\%), Sample-C (9\%)) (Fig. 1-5; Table 2-5)

This research finally leads to the formulation of healthy biscuits incorporated with carrot Powder as functional ingredients. On the basis of nutritional and sensory quality, biscuit when incorporated with $6 \%$ carrot powder resulted in better quality.

\section{References}

Akinola, b T. O. Malomo (2016) Dehydration Characterization of Carrot (Daucus Carota) Slices Dried Using the Refractance Window ${ }^{\mathrm{TM}} \quad$ Drying Technique, Zimbabwe Journal of Science \& Technology pp 28- 38, Vol.11 [2016] Zimbabwej.sci.technol.
Alklint, C., Wadso, L. and Sjoholm, I. (2004). Effects of modified atmosphere on shelf-life of carrot juice. Food Control. 15:131-137.

Baljeet, S.Y., Ritika, B.Y. and Reena, K. (2014). Effect of incorporation of carrot pomace powder and germinated chickpea flour on the quality characteristics of biscuits. Intern. Food Res. J. 21: 217-222.

BazillaGayas, Rama NathShukla, BeenaMunaza Khan (2012) Physico Chemical and Sensory Characteristics of Carrot Pomace Powder Enriched Defatted Soyflour Fortified Biscuits International Journal of Scientific and Research Publications, Volume 2, Issue 8, August 2012.

Bohm V, Otto K and Weissleder F (1999). Yield of juice and carotenoids of the carrot juice production. In: Symposium Jena-Thuringen, Germany.

Dias, J.S. (2012) Nutritional Quality and Health Benefits of Vegetables: A Review. Food and Nutrition Sciences, 3, 1354-1374.

Donald G. Mercer (2014) An Introduction to the Dehydration and Drying of Fruits and Vegetables.

EfuribeNnenna, Akinwale Toyin, Owolabi Folasade (2017) Development and Quality Evaluation of Carrot Powder and Cowpea Flour Enriched Biscuits International Journal of Food Science and Biotechnology.

Gazalli, H., Malik, A.H., Jalal, H., Afshan, S. and Mir, Ambreen. (2013). Proximate composition of carrot powder and apple pomace powder. Intern. J. Food Nutri. Safety. 3(1): 25

Humaira Gazalli, AltafHussain Malik, Heena Jalal, Saima Afshan (2013) Proximate Composition of Carrot Powder and Apple Pomace Powder International Journal of Food Nutrition and Safety, 2013, 3(1): 25-28. 
Kumar Navneet, Sarkar B.C. and Sharma H.K. 2010. Development and characterization of extruded product using carrot pomace and rice flour". International Journal of Food Engineering, Vol. 6, No. 3, Art. 7. DOI:10.2202/1556-3758.1824, 2010.

Kumar, N. and Kumar, K. (2011). Development of carrot pomace and wheat flour based cookies. J. Pure and Applied Sci. Technol.

Monishachoudhury (2016) development and acceptance analysis of mixed fruit pomacefortied high-fibre biscuits, Proceedings of IRF International Conference, 29th and 30th October, 2016, Chennai, India.

Nimesh Chauhan, Jethva KR. (2015) Drying Characteristics of Banana Powder. Indian Journal of Science, 2016, 23(77), 75-88.

Olapade AA, Aworh OC, Oluwole OB (2011). Quality attributes of biscuit from acha flour supplemented with cowpea flour. African Journal of Food Science and Technology. 2:198-203.

Rakesh Singh, Drying and Dehydration of Fruits and Vegetables.
Sharma, H.K., J. Kaur, B.C. Sarkar, C. Singh, and B. Singh. 2007. Effect of pretreatment conditions on physicochemical parameters of carrot juice. Int. Journal of Food Science and Technology.

Sindhu, Hruyia. L, ShwetaSaloni, Harshavardhan. K, Mounika. B, Kalyani. D, Pavankumar. N.S, Narayana. M.V. (2012) Development of Biscuit Incorporated With Defatted Soya Flour and Carrot Pomace Powder. IOSR Journal of Environmental Science, Toxicology and Food Technology.

Soma Srivastava and Kalpana Kulshreshtha (2012). Nutritional Content and Significance of Tomato Powder, GovindVallabh Pant University of Agriculture and Technology, Pant Nagar 263 145, India, Received: May 2012.

Speizer FE, Colditz GA, Hunter DJ, Rosner B, Hennekens C (1999). Prospective study of smoking, antioxidant intake and lung cancer in middle aged women. Cancer Causes Control 10:475.

\section{How to cite this article:}

Mounika, G. and Srinivas Maloo. 2018. Development and Sensory Evaluation of Biscuit by Incorporation of Carrot Powder. Int.J.Curr.Microbiol.App.Sci. 7(04): 2583-2592. doi: https://doi.org/10.20546/ijcmas.2018.704.294 